\title{
Corporate social responsibility: Polish experience and Ukrainian perspectives
}

\section{Valeriya Fadyeyeva, Adam Mickiewicz University}

Global issues of 21 century, such as ecological concerns, depletion of natural resources, informatization, transition to the machine production and switch to the predominance of intellectual work have led to the changes in the social role of large business. Best world practice along with UN recommendations strongly support the development of socially responsible business. Global network of multinational companies allows them to predetermine political and social situation in many countries sometimes more effectively than traditional politics. Positive correlation between business performance and purchasing power of citizens accentuate the importance of investment into social development. Consequently, the corporate social responsibility (CSR) becomes one of the cornerstones of sustainable development.

This paper aims to describe basic principles of CSR and its historical development, to analyze pros and cons of different approaches to CSR and discuss the perspectives of its implementation into Ukrainian economy using Polish experience.

E. Garriga and D. Mele in their article «Corporate social responsibility Theories: Mapping the Territory» managed to perfectly describe almost all theories of CSR, allowing many scientists to use their results. In spite of positive social influence of CSR, its impact on economic still remains unclear. It may be connected to the relatively short follow-up for the tracking of economic changes and the difficulties for the estimation of such complex phenomenon.

Transitional Ukrainian economy just have started the implementation of corporate social responsibility (CSR), and sometimes it lack the deep understanding of what that means and how that works. Polish experience may become a good example for eastern neighbor`s companies and government, and help to build new relations between large business and society.

Keywords: corporate social responsibility (CSR); Polish-Ukrainian relations; implementation of CSR in Ukraine; pros and cons of CSR

\section{Корпоративна соціальна відповідальність: польський досвід та українські перспективи}

\section{Валерія Фадєєва, Університет імені Адама Міцкевича}

Глобальні виклики 21 століття, серед яких екологічні проблеми, виснаження природних ресурсів, інформатизація, перехід до машинного виробництва та зміна пріоритетів на користь переважання розумової праці призвели до метаморфози соціальної ролі великого бізнесу. Кращий світовий досвід, а також рекомендації $\mathrm{OOH}$ рішуче підтримувати розвиток соціально відповідального бізнесу. Глобальна мережа транснаціональних компаній дозволяє їм заздалегідь визначити політичну і соціальну ситуацію в багатьох країнах іноді більш ефективно, ніж традиційна політика. Позитивна кореляція між економічною успішністю бізнесу та купівельною спроможністю громадян підкреслює важливість інвестицій у соціальний розвиток. Отже корпоративна соціальна відповідальність (КСВ) стає одним із наріжних каменів сталого розвитку.

Метою даної статті є опис основних принципів КСВ та ії історичного розвитку, аналіз плюсів і мінусів різних підходів до КСВ та обговорення перспектив впровадження КВС в українську економіку з використанням польського досвіду.

E. Garriga i D. Mele в їхній роботі «Теорії корпоративної соціальної відповідальності: картографування території» вдалося чудово описати майже всі теорії КСВ, що дозволило багатьом вченим використовувати їхні результати. Незважаючи на позитивний соціальний вплив КСВ, його вплив на економіку залишається неясним. Це може бути пов'язано з відносно коротким терміном спостереженням за економічними змінами від моменту початку активного використання принципів КСВ та труднощами для оцінки такого складного явища.

Перехідна українська економіка лише почала впроваджувати корпоративну соціальну відповідальність (КСВ), у зв'язку з чим іноді їй бракує глибокого розуміння того, «що це означає?» і «як це працює?». Польський досвід може стати хорошим прикладом для компаній і уряду східних сусідів, а також допомогти побудувати нові відносини між великим бізнесом і суспільством.

Ключові слова: корпоративна соиіальна відповідальність (КВС); польсько-украӥнські відносини; впровадження КСВ в Україні; плюси і мінуси КСВ 


\section{Корпоративная социальная ответственность: польский опыт и украинские перспективы}

\section{Валерия Фадеева, Университет имени Адама Мицкевича}

Глобальные вызовы 21 века, среди которых экологические проблемы, истощение природных ресурсов, информатизация, переход к машинному производству и изменение приоритетов в пользу преобладания умственного труда привели к метаморфозе социальной роли крупного бизнеса. Лучший мировой опыт, а также рекомендации ООН, решительно поддерживать развитие социально ответственного бизнеса. Глобальная сеть транснациональных компаний позволяет им заранее определить политическую и социальную ситуацию во многих странах, иногда более эффективно, чем традиционная политика. Положительная корреляция между экономической успешностью бизнеса и покупательной способностью граждан подчеркивает важность инвестиций в социальное развитие. Таким образом, корпоративная социальная ответственность (КСО) становится одним из краеугольных камней устойчивого развития.

Целью данной статьи является описание основных принципов КСО и ее исторического развития, анализ плюсов и минусов различных подходов к КСО и обсуждения перспектив внедрения КВС в украинскую экономику с использованием польского опыта.

E. Garriga и D. Mele в работе «Теории корпоративной социальной ответственности: картографирование территории» удалось прекрасно описать почти все теории КСО, что позволило многим ученым использовать их результаты. Несмотря на положительное социальное влияние КСО, ее влияние на экономику остается неясным. Это может быть связано с относительно коротким сроком наблюдения за экономическими изменениями с момента начала активного использования принципов КСО и трудностями при оценки такого сложного явления.

Переходная украинская экономика только начала внедрять корпоративную социальную ответственность, в связи с чем иногда ей не хватает глубокого понимания того, «что это значит?» и «как это работает?». Польский опыт может стать хорошим примером для компаний и правительства восточных соседей, а также помочь построить новые отношения между крупным бизнесом и обществом.

Ключевые слова: корпоративная сочиальная ответственность (КСО); польско-украинские отношения; внедрение КСО в Украине; плюсы и минусы КСО

\section{Problem definition}

$\mathrm{D}$ uring last few decades, the idea of corporate social responsibility has evolved from theoretical concepts to the complex system of different approaches widely used all over the world. Globalization and regional integration lead to the changes in the social values of different institutions including governments, NGOs and business. Many research declare the lowest historical levels of the public trust to the government [17] both in US, many countries of the European Union (except Denmark, Switzerland, Netherlands, Luxembourg and Nordic countries) [22] and in Ukraine [5]. This fact on the one side and the powerful development of multinational corporations at the other side create strong potential for them to influence on the main social processes, sometimes more effective than politics can do [10].

Ecological concerns, depletion of natural resources, global informatization, transition to the machine production and switch to the predominance of intellectual work have led to the increased need in the socially responsible business. These processes were initiated in the early 20th in USA but soon expanded to the remaining capitalistic part of the world. After the collapse of socialistic regimens on the territory of Eastern Europe, its countries - among them Poland and Ukraine, have started their own way of implementation of good business practices into economic reality.

In the light of Ukrainian eurointegration the analysis of Polish experience in the different fields should help understand key points of the successful way to this destination. Moreover, strong economic, political, social and cultural cooperation between two countries creates unique perspectives for further bilateral development.

Purpose of the research is to describe, to analyze and to compare systems of corporate social responsibility (CSR) in Poland and Ukraine.

Analysis of the research and publications: Historical development and main characteristics of CSR

Roots of contemporary conception of «corporate social responsibility», or simpler CSR, lay in the thirties of 20th century when Henry Ford, the 
president and main shareholder of Ford Motor Company, stated that dominant purpose of his company was to serve the society $[3,41]$. H. Bowen made first steps towards theoretical describing of this socioeconomic phenomenon in 1960th $[2,64]$. In the book «Social Responsibilities of the Businessman» author tried to find the answers about what must guide businesses to create welfare of society. He declares that executives should understand their obligations, chose those decisions and follow those policies that reflect objectives and values of society. Bowen was first to describe in details and analyze the terms of CSR, its' connection to the institutional changes at the start of new century. This way of thinking now is recognized as ethical obligational theory. Carroll called H. Bowen as «Father of Corporate Social Responsibility» [4].

P. Drucker [6, 73] and A. Carroll continued and expanded Bowen's conceptions enlarging the list of business obligations in front of society. Moreover, they stated that goals of CSR must to be set according to main political and social issues. Summarizing their concepts, several points should be emphasized [8]:

- Corporate managers may become new public trustees;

- Philanthropy may be the manifestation of business support of main social needs;

- Corporate resources should be claimed on a competitive basis.

Moving forward to the present days, more theories of CSR have emerged reflecting mainstreams in economics and social sciences. Since nineties until now, key ideas of CSR have invaded almost all component parts of society starting from of course corporations and governments to consumers and NGOs. Since the establishment of UN Global Compact [24] many international organization including the International Labor Organization and the World Bank have strongly supported the movement of CSR and created many strict rules for the companies. The reasons for such policies are clearly understandable taking to account the social impact of key international business players.

Main concepts of CSR described in 20th century were concentrated around the philanthropy and charity. Since then we shifted to the deeper understanding of this concept. Today CSR is about how companies earn their profit, but not about how they spend it. In the age of third industrial revolution [22], multinational corporations and large business get under strong pressure from the international organization, internet societies and governments that claim for the increasing of CSR measures.

Nowadays, all theories of CSR may be classified in several categories. Nevertheless, one thing should be kept in mind - despite numerous studies dedicated to CSR there is still no generalized understanding what it mean. Different social players have its own description of CSR that meets main their issues. For someone, this is the idea of liability; for others this is a kind of social consciousness; third part may describe it as a set of tools for good business practice [26]. Many researchers tried to classify CSR correctly [7], and the most fundamental system was proposed by

E. Garriga \& D. Mele in their work «Corporate social responsibility Theories: Mapping the Territory» [10]:

- Instrumental theories indicate business as an instrument for wealth creation. This group comprises several points - 1) maximizing the shareholder value; 2) strategies to achieve competitive advantage include strategies for the bottom of the economic pyramid targeting the poor group of consumers, social investment in a competitive context is about philanthropic activity; 3) natural resource-based view of the firm and dynamic capabilities - the set of routine tools for managers to acquire, modify, integrate and recombine resources; 3 ) cause-related marketing defend the principle «good company reputation - good ecumenical performance»;

- Political theories comprises three major directions - corporate constitutionalism, integrative social contact theory and corporate citizenship.

Corporate constitutionalism consider the CSR as an integral component of any business setting, and according to «the iron law of responsibility» each party that has a social power ought to use it aiming to achieve welfare. Otherwise, firm loses its social power and positions because other corporation, willing to take this responsibility, occupy it.

Main issue of integrative social contact theory is based on the assumption that there is an implicit social contract between business and society. Thus, it creates obligation of firms towards society.

The corporate citizenship treat business as a citizen. Simple explaining tells us - in the globalized world, some large multinational companies have a greater economic and social influence that country' governments.

- List of integrative theories comprises:

o Issue management;

o The principle of public responsibility;

o Stakeholder management;

o Corporate social performance. 
General description of integrative theories consists in the principle «no society - no business». Thereby, the last should create necessary environment for the maintenance and development of society.

Issue management describes the process for making a corporate response to social issues. In some kind, it correlates with the anti-crisis management and consulting when companies should identify, evaluate and effectively respond to the political and social circumstances, which may significantly affect their performance [23].

Principle of public responsibility emphasizes the importance of public process rather than personalmorality views defining the scope of responsibilities. Public opinion and emerging tendencies may have stronger impact on the needs in CSR. In the same time, business may join to a public police process especially in the areas where it is not clearly established yet.

Stakeholder management is very interesting and important theory of CSR. Instead of focusing on the final consumers, CSR should target interests of the stakeholders of the company. The main goal - achieving the best cooperation between all stakeholder groups and their welfare. This strategy has been widely used since early development of CSR. In spite of lacking a good theoretical basis, it shows good and reliable results. Thought it should be considered as inalienable part of CSR.

Last but not the list - corporate social performance tries to unite and integrate previous points.

- Set of ethical theories includes normative stakeholder theory, universal rights, the common good approach and sustainable development.

Normative stakeholders tells us about the equilibrium between the interests of company's stockholders and stakeholders. It is liberal approach reflecting modern theories of property, Kantian capitalism and distributive justice. Universal rights is close to the first point, but it concentrates on the superiority of human rights. The good example is UN Global Compact that declares nine basic principles in the fields of human rights, labor and environment derived from The Universal Declaration of Human Rights; The International Labor Organization's Declaration on Fundamental Principles and Rights at Work; and The Rio Declaration on Environment and Development [20].

The concept of sustainable development has become very popular during last years. According the UN, sustainable development comprises the set of goals for a better more sustainable future for all. First of them include fighting poverty and hunger, struggle for good health and well-being, quality education, gender equality, constant access to the clean water and sanitation, affordable and clean energy [1]. Term "sustainable development» was first used in the Brutland Report, published in 1987 by the World Commission on Environment and Development (UN) [18]. Now it is defined as the process of economic and social changes, which satisfy human development goals sustaining the ability of natural systems to provide the necessary natural resources upon which the economy and society depend. Thus, large business plays one of key roles in the achievement of listed goals having most of necessary instruments and resources.

The common good approach is an example of combination of different ethical principles of antiquity, Medieval times and Catholic social views.

In this paragraph, we paid attention to the main concepts of corporative social responsibility and its role in the business and social development. CSR started in United States, gradually captured the world and became the etalon for good business practice in most countries. There is no statement on the economic impact of CSR. Studies of late nineties declared positive correlation between the implementation of CSR and financial performance of companies [9]. J. Frooman showed that social irresponsibility leads to the economic losses and the negative effect on the wellbeing of shareholders. Other studies had a corresponding results proving that CSR maximize corporate profits and accelerates corporate development [12]. Vice versa, some other studies failed to find positive correlation between the use of CSR and financial advantage [19]. Leaving economic questions beyond, one thigh stays undoubtful - CSR plays significant role in the development of harmonious society at the turn of the millennium.

Main material: CSR in Poland and in Ukraine

Corporate social responsibility in Poland: example of successful implementation in postsocialistic country

The economic report «15 polskich przykładów społecznej odpowiedzialności biznesu», or 15 examples of polish corporate social responsibility describes several companies that managed to fully implement CSR principles into the practice. Among them Euro Bank S.A., L'Oreal, DHL, Citi Handlowy, Procter \& Gamble, Coca-Cola, GlaxoSmithKline, Kompania Piwowarsca etc [14]. According to the research of PwC consulting firm 229 of 287 (80\%) 
large and medium companies achieved financial advantages by using of long-term strategies. The most active were the companies from the fields of power and heat engineering, financial area, wood and paper, automotive and chemical industries [27]. Although, 67 percent of companies declares priorities connected to business activities that correspond with the principles of corporate social responsibility. All above-mentioned firms imply different CSR methods including implementation of safety standards and the quality of products and services $-93 \%$; focusing attention on standards of customer service $-92 \%$; paying attention to the equal customers access to products and services - 42\%; promoting sustainable consumption and informed decision-making $-24 \%$. Moreover, $85 \%$ of companies mentioned that they provide CSR activities in the field of science, education, cultural and social institution organizations. Two thirds of all respondents noted the presence of ethical rules principles and guidelines and declared priorities in carrying out business in accordance with basic principles of corporate social responsibility [15] mostly in the field of HR-policy.

In the same time it should be noted that only $46 \%$ of responders mark CSR as a part of business strategy and only $39 \%$ of companies had an independent CSR department. Consequently, it poses a question about the contemporary place of CSR in the polish business. Moreover, many experts affirms that corporate social responsibility have just started its way in polish economy and should overcome many obstacles to reach the level of US and Western European companies. It appears that primary problem is in lack of understanding of CSR principles among the majority of entrepreneurs in Poland. It results in the attempts to conduct CSR activity in the form of simple philanthropy that violates the primary principle $" \mathrm{CSR}$ is about how companies earn their profit, but not about how they spend it».

Summarizing, today Poland show a good progress in the development of social responsible business that could be an example for other countries of Eastern Europe. However, Polish companies still frequently confuses the original concepts of CSR with their simpler analogues.

Corporate social responsibility in Ukraine: the analysis of main tendencies and perspectives of future development

According to the different social studies conducted mostly in the early the twenties of the twenty-first century, the number of «socially responsible» businesses in Ukraine accounts about 70 companies [11]. As well as society, the Ukrainian economy remains in a transitional state trying to catch up with major part of capitalistic word. This means that each field of economic and social life started to implement the best world practices including CSR. Being an integral part of sustainable development CSR becomes one of essentials for medium and large business in Ukraine.

Unlike many other European countries, in Ukraine the development of CSR is conducted via special scenario - the companies itself took on the initiative, developing practices of socially responsible behavior, engaging in such activities other players - consumers, NGOs, governmental representatives on regional and national levels. The absence of external influence, in other words - social order on CSR, caused its special features Ukraine. CSR became attractive because the necessity to evolve from short-term business projects to sustainable companies with long-term strategies [16].

The main problem of the Ukrainian CSR segment is somehow similar to Polish. Companies lack in a true notion of social responsibility and consequently try to use philanthropy of charity instead of implementation of full-scale SCR strategies [13].

Estimating the impact of CSR measures on corporate strategy of Ukrainian companies, the following conclusions may be done: improvement of the attitude of employees to the company is about $70 \% ; 62 \%$ of Ukrainian companies believe that they have brought real benefits to society and community; company reputation improved in $46 \%$ and economic performance in $48 \%$. Thus, the development and use of CSR in any industry increases the efficiency of its socio-economic functioning by creating conditions for company's responsibility to its shareholders, stakeholders and society, and supports welfare as a whole [25].

Corporate social responsibility means the complex system of social-friendly business strategies aiming to provide sustainable development for the company by investing in the development of community. Many people tend to interpret this phenomenon from the view of PR industry but the roots of necessity of CSR lays much deeper. To understand the nature of CSR one need to ask himself a fundamental question - "what is the business without society?" The answer to it will lead to the understanding of great social demand for responsible business activity. Paying capacity, the level of living, education, finally - public health and the lifetime are connected directly to social needs in 
goods and services. Thus, CSR today is not a good will of industry, it is an integral part of its existence.

Analyzing different scientific methods to study CSR activity in Poland and Ukraine, we should focus attention on their high subjectivity. How is it possible to estimate fundamental society changes after implementing one or other CSR measure? Even if possible, than very difficult. Modern Ukrainian industry has a bad habit to target mostly short-term programs with clear results and financial advantages. Polish situation show better understanding of what CSR is in real. It should take some time for post-socialistic countries and theirs citizens to shift the focuses from the faith in necessity of paternalistic government position to the corporate social responsibility.

\section{Conclusions}

The article describes and analyzes historical development and leading scientific concepts of corporate social responsibility. The essential part of its evolution occurred in the second half of the twentieth century and converted CSR into one of basic community needs.

The main problem of the Ukrainian and Polish CSR segment is the lack of a true notion of nature of social responsibility and, consequently, trying to realize it as the philanthropy of charity instead of implementation of full-scale SCR strategies. Understanding of the global need of CSR should harry up the process of its development.

\section{REFERENCES}

1. About the Sustainable Development Goals. Retrieved from: https:/www.un.org/sustainable development/ sustainable-development-goals/

2. Bowen, H.R. (2013). Social responsibilities of the businessman. University of Iowa Press. Iowa City.

3. Carroll, A.B. (2008). A history of corporate social responsibility: Concepts and practices. The Oxford handbook of corporate social responsibility. Oxford

4. Carroll, A.B. (1999). Corporate social responsibility: Evolution of a definitional construct. Business \& society, $38,268-295$.

5. Dovira hromadian Ukrainy do suspilnyh instytutiv. Resultaty sociolohichnoho doslidjenia. (2018). Retrieved from: http://razumkov.org.ua/uploads/socio/2018_06 press_release_ua.pdf [in Ukrainian]

6. Drucker, P. (2012). The practice of management. Routledge. London.

7. Frederick, W.C. (1998). Moving to CSR: What to Packfor the Trip. Business \& Society, 37, 40-59.

8. Frederick, W.C. (1960). The growing concern over business responsibility. California management review, 2 (4), 54-61.

9. Frooman, J. (1997). Socially irresponsible and illegal behavior and shareholder wealth: A meta-analysis of event studies. Business \& society, 36, 221-249.

10. Garriga, E., \& Melé, D. (2004). Corporate social responsibility theories: Mapping the territory. Journal of business ethics, 53 (1-2), 51-71.

11. Grishnova, O.A. (2011). Social `na vidpovidal `nist`u konteksti podolannya sy`stemnoyi kry`zy`v Ukrayini [Social responsibility in the context of overcoming the systemic crisis in Ukraine]. Demografiya ta social'na ekonomika, 1, 15 [in Ukrainian].

12. Key, S., \& Popkin, S. J. (1998). Integrating ethics into the strategic management process: Doing well by doing good. Management Decision, 36 (5), 331-338.

13. Harlamova, A.O. (2012). Korporaty`vna social`na vidpovidal`nist` neobxidny`j chy`nny`k formuvannya korporaty`vnoyi strategiyi [Corporate social responsibility is a necessary factor in the formation of a corporate strategy]. Efekty vna ekonomika, 9 [in Ukrainian].

14. Kuraszko, I., \& Augustyniak, S. (2009). 15 polskich przykładów społecznej odpowiedzialności biznesu. Forum Odpowiedzialnego Biznesu.

15. Mączyńska, E. (2011). Dysfunkcje gospodarki w kontekście ekonomii kryzysu. Zeszyty Naukowe, 9, 43-70.

16. Polyakova, O.M. (2013). Korporaty`vna social`na vidpovidal`nist`v Ukrayini [Corporate Social Responsibility in Ukraine]. Visny 'k ekonomiky` transportu i promy slovosti, 44, 279-283 [in Ukrainian].

17. Public Trust in Government: 1958-2017. Retrieved from: http://www.people-press.org/2017/12/14/public-trustin-government-1958-2017/

18. Report of the World Commission on Environment and Development: Our Common Future. Retrieved from: http:// www.un-documents.net/our-common-future.pdf

19. Rowley, T.J. (1997). Moving beyond dyadic ties: A network theory of stakeholder influences. Academy of management Review, 22 (4), 887-910.

20. The Nine Principles of the Global Compact. Retrieved from: https://www.unglobalcompact.org/ system/ attachments/7618/original/Zenith.pdf?1282019232

21. The third industrial revolution. (2012). The Economist. Retrieved from: https://www.economist.com/ leaders/2012/04/21/the-third-industrial-revolution 
22. Soderlund, P. (2017) Trust in politicians across countries and over time. Retrieved from: http://blogs.uta.fi/ contre/2017/11/02/trust-in-politicians-across-countries-and-over-time/

23. Starosta, A. (2014). Anti-crisis management strategies. The case of companies in the Greater Poland Voivodeship. Management, 18 (1), 255-266.

24. United Nations Global Compact. Retrieved from: https://www.unglobalcompact.org/ what-is-gc

25. Votaw, D. (1972). Genius becomes rare: A comment on the doctrine of social responsibility Pt. I. California management review, 15 (2), 25-31.

26. Voloskovecz', N.Yu. (2010). Korporaty`vna social’na vidpovidal'nist' pidpry`yemstv yak osnova innovacijnogo rozvy 'tku suchasnoyi ekonomiky` [Corporate social responsibility of enterprises as the basis of innovative development of modern economy]. Naukovi praci Kirovograds `kogo nacional'nogo texnichnogo universy 'tetu. Ekonomichni nauky, 17, 125-130 [in Ukrainian]

27. Wolska, G., \& Kizielewicz, J. (2015). Corporate social responsibility in Poland-theory and practice. In DIEM: Dubrovnik International Economic Meeting, 2 (1), 143-153. Sveučilište u Dubrovniku.

\section{Фадсєва Валерія Едуардівна}

Аспірант

Університет імені Адама Міцкевича

61-712, м. Познань, вул. Венявського, 1

Email:v.fad@ukr.net

\author{
Fadyeyeva Valeriya \\ Postgraduate student \\ Adam Mickiewicz University \\ 1, Wieniawskiego Str., Poznań, 61-712, Poland
}

Цитування: Фадєєва В. Е. Корпоративна соціальна відповідальність: польський досвід та українські перспективи / В. Е. Фадєєва // Науково-теоретичний альманах «Грані». - 2019. - Т. 22. - № 3. C. 95-101.

Citation: Fadyeyeva, V.E. (2019). Corporate social responsibility: Polish experience and Ukrainian perspectives. Scientific and theoretical almanac «Grani», 22 (3), 95-101. 